Topiques, études satoriennes

Topoï Studies, Journal of the SATOR

\title{
Food, Drink and the Other: Producing Satire and Otherness in Portuguese Literature
}

\section{Constança Viera de Andrade}

Volume 5, 2021

Le manger et le boire dans la fiction narrative

URI: https://id.erudit.org/iderudit/1081522ar

DOI: https://doi.org/10.7202/1081522ar

See table of contents

Publisher(s)

SATOR, Société d'Analyse de la Topique Romanesque d'Ancien Régime

ISSN

2369-4831 (digital)

Explore this journal

Cite this article

Viera de Andrade, C. (2021). Food, Drink and the Other: Producing Satire and Otherness in Portuguese Literature. Topiques, études satoriennes / Topoï Studies, Journal of the SATOR, 5, 27-50. https://doi.org/10.7202/1081522ar
Article abstract

Portuguese narrative fiction is plentiful of food and drink references, which vary in meaning and function accordingly to the historical context of production. The peripathetic Portuguese brought culinary knowledge from abroad mainly since the 16th century, merging cultural changes of food and drink with practices from their country of origin. This was a turning point in the history of Portuguese narrative fiction, for it made more present the concept of the "other" through consumption habits. An extremely short travel between 16th and 19th narrrative fiction examples intends to highlight some uses of food and drink as topoi in historical and cultural context, asserting the relevance of this resource to articulate identities and alterities.
This document is protected by copyright law. Use of the services of Érudit (including reproduction) is subject to its terms and conditions, which can be viewed online.

https://apropos.erudit.org/en/users/policy-on-use/ 


\section{Food, Drink and the Other: \\ Producing Satire and Otherness in Portuguese Literature}

Constança Viera de Andrade

CRIA/ ISCTE-IUL

Food appears in Portuguese narrative fiction and drama both as an element of reality and with a symbolic function, and authors often combine these two aspects for literary enrichment. Throughout the centuries, food and consumption habits have been among the most widely used resources in creating fictional identities and highlighting social differences between characters or groups in Portuguese literature. This article opens with a historical approach beginning with the Portuguese expansion (in 1415, with the taking of Ceuta), with the intention of highlighting how Portuguese narrative literature has employed food in portraying interactions between different identities or cultures, and to illustrate how appropriations of and confrontations with food products and habits occurred. As a result, the symbolic charge of food enables an understanding of how alterities / notions of the "other" - of race / ethnicity, country, class, religion, gender are produced, and how concepts of self and other are necessarily built up and articulated with each other. Settings of both food preparation and consumption are of capital importance to the authors' strategies for communicating elements of diverse identities to their readers. By highlighting a few chosen Portuguese literary works, this article illustrates the use of food and drink to create topoi of otherness at particular historical moments. Descriptive styles, the interweaving of food and drink, material culture, spaces of "performance" and psychological peculiarities further provide an effective dialectic between distinct characters and their contexts creating colorful, picaresque and attractive literary pieces. The final, longer section on the literary production of Eça de Queirós reflects the particular relevance that food and drink assume in two fundamental pillars of his work: cultural identity and otherness. The final purpose of this article is to contribute to the knowledge about historical construction and articulation of different identities through the various means of preparing and consuming food and drink. 


\section{The Discovery of a New World}

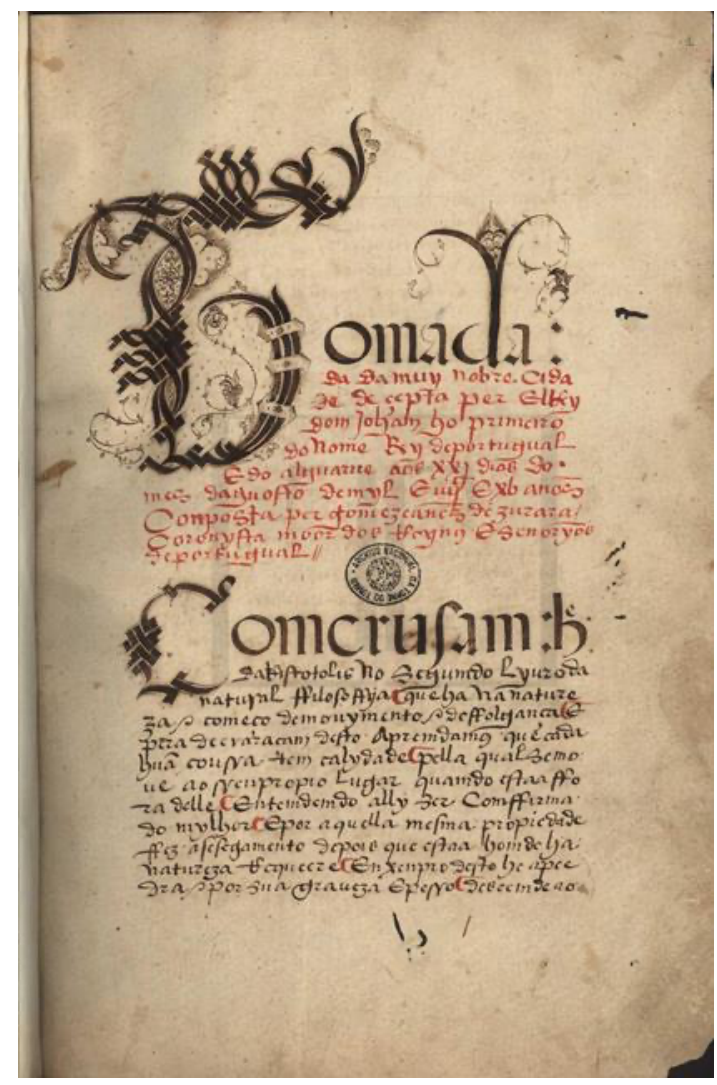

Figure 1: Page 1 of The Chronicle of the Taking of Ceuta by King John the 1st of Portugal. Source: Zurara, Gomes Eanes de, Crónica da tomada de Ceuta por el-rei D. João I, Lisboa, Academia das Ciências (Série vermelha, n.o 1767), 1915 [1450]. Torre do Tombo, Biblioteca. Public domain. https://antt.dglab.gov.pt/exposicoes-virtuais-2/conquista-de-ceuta/

The Chronicle of the Taking of Ceuta by King John the $1^{\text {st }}$ offers a description of the feasts ordered in the town of Viseu (Portugal) by Prince Henry (called "The Navigator") to commemorate his departure for the conquest of Ceuta, during the period between Christmas Eve of 1414 and Epiphany (the Day of the Three Wise Kings) of 1415. A great abundance of sugar treats and preserves were brought from different parts of the kingdom, including spices and green and dry fruits, barrels of Malvasia, and white and red wines of the best quality. These delicacies were chosen for consumption in a feast that marked the beginning of the Portuguese expansion. From then on, contact with other cultures would come to play a permanent role in the construction of identity in Portugal.

The reports and chronicles produced during the Portuguese maritime expansion reveal curiosity and fascination, articulating ways of seeing otherness. The foodstuffs of the new worlds were incorporated into the diets of various Portuguese social strata, 
including daily and festive dishes. How did these new products find their way to the tables and stomachs of the Portuguese and what meanings did they acquire during that process?

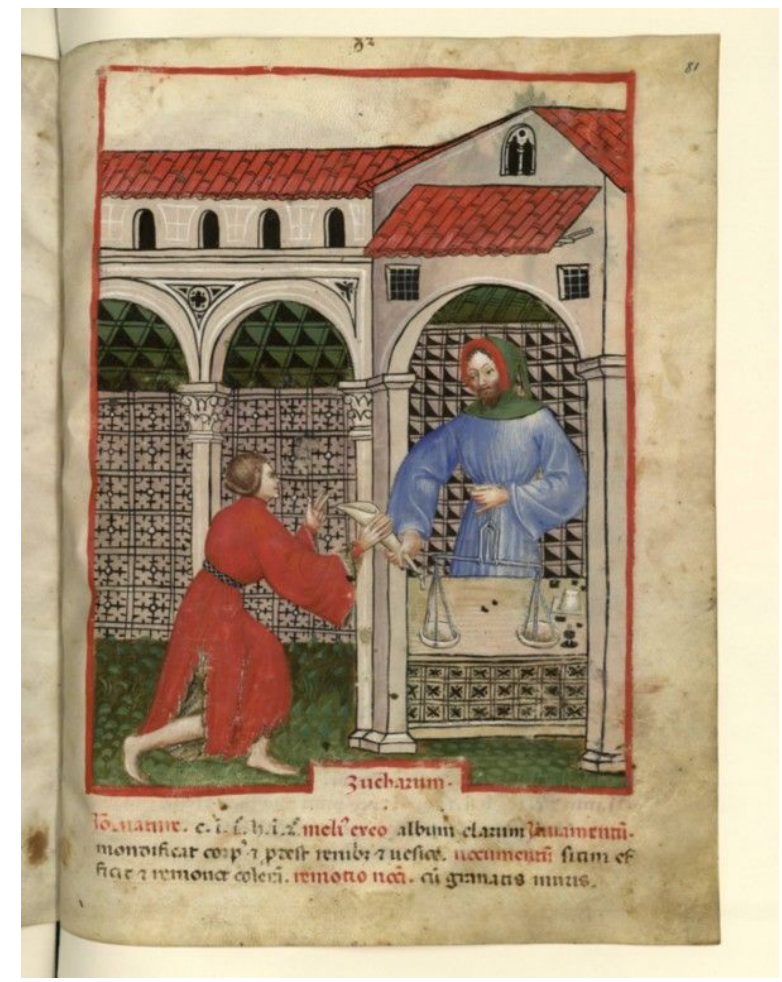

Figure 2: Sugar merchant. Tacuinum sanitatis, Milano or Pavie, 1390-1400. Public domain. https://www.pinterest.ca/pin/491455378082679376/

Imported sugar became one of the most important products of Portuguese food culture, available almost exclusively to the upper social classes (both as a preservative and a cooking ingredient) and for medicinal use until the $20^{\text {th }}$ century. Until the $19^{\text {th }}$ century, sugar was also prepared in a sophisticated way in women's convents and monasteries in Portugal ${ }^{1}$ and given as an offering to their patrons. By facilitating contact with the world outside the enclosed space of the convent, food enabled liaisons between nuns and (aristocratic) lovers, with men exchanging poems for conventual sweets in a courtship ritual. Sugar has thus been configured as a facilitator of interaction between two social spheres, spatially separated by physical structures designed to be enclosed by rigid rules and conventions. Sweets also served as goods for gifts and exchanges of favors,

\footnotetext{
${ }^{1}$ Convents and monasteries could be for either women or men, or - less frequently - a mix of both (called duplex) until the $11^{\text {th }} / 12^{\text {th }}$ century. Afterwards, all convents and monasteries in Portugal were for either one gender or the other. The making and offering of sweets by nuns to their patrons was exclusive to women's establishments.
} 


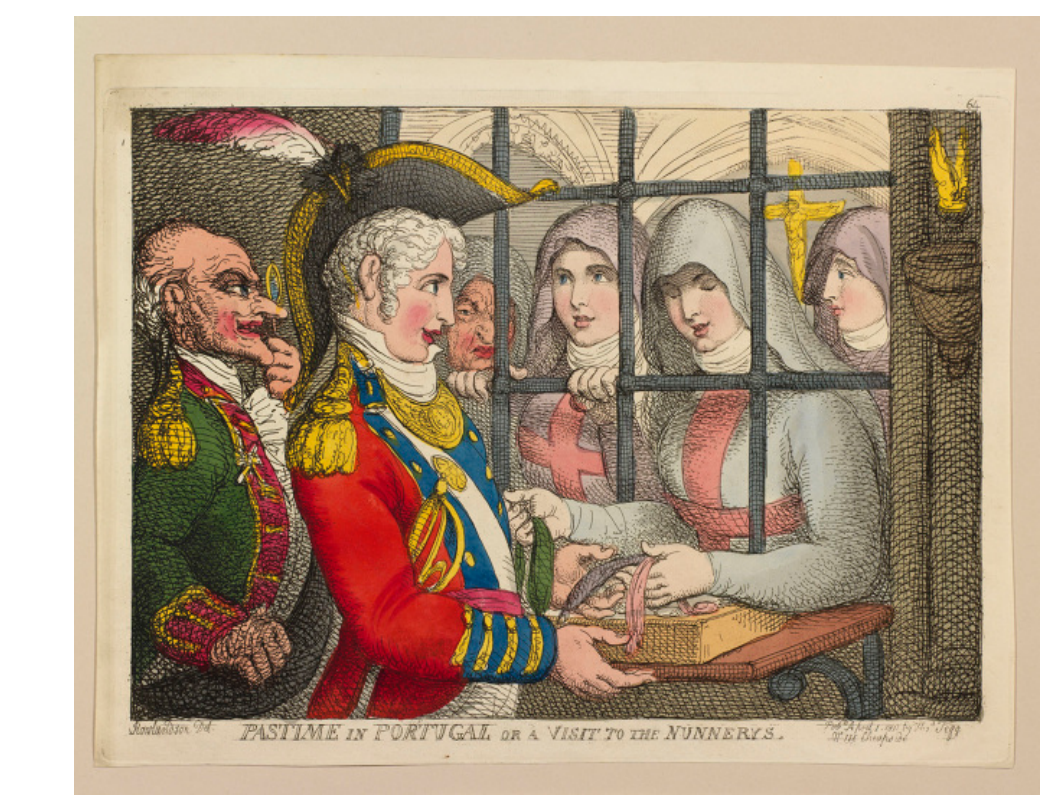

Figure 3: Thomas Rowaldson, Pastime in Portugal or a visit to the nunnerys, 1811. The Metropolitan Museum of Art. Public domain.

https://www.metmuseum.org/art/collection/search/787945

within both ecclesiastical and civil life. This use of prestigious food to thank or motivate the granting of benefits is intrinsic to Portuguese culture and remains current in the $21^{\text {st }}$ century. An allegory from c. 1526 by the playwright Gil Vicente (c.1465-c.1536) satirized the gastronomic value of the partridge, appreciated and consumed by the higher classes, and therefore used as bribery in exchange for favors:

Se tu diante lhe deitas

Duas dúzias de perdizes,

E outras semelhantes penitas

Farás que as varas direitas

Se tornem em cousas fritas. ${ }^{2}$

In a time when the direct exchange of goods was parallel to or even more frequent than money payments, the worth of some food delicacies increased - as was the case for the partridge - and these items were often used to pay for intangible benefits (namely favors).

In Gil Vicente's works, food genres often contribute to characterization. The onion is associated with marginality, such as the Fool character, who with his disrespect towards social conventions is the driving force in the Auto da Barca do Inferno (Play of the Ship of Hell) as well as with the Sorceress, who uses onions in potions. The intense

\footnotetext{
${ }^{2}$ Gil Vicente, Auto da Festa, 1906, p. 101. "If you put it on / Two dozen partridges/ And other similar
} feathered birds/ You will make sticks / Turn into fried things." (My translation, unless otherwise indicated). 


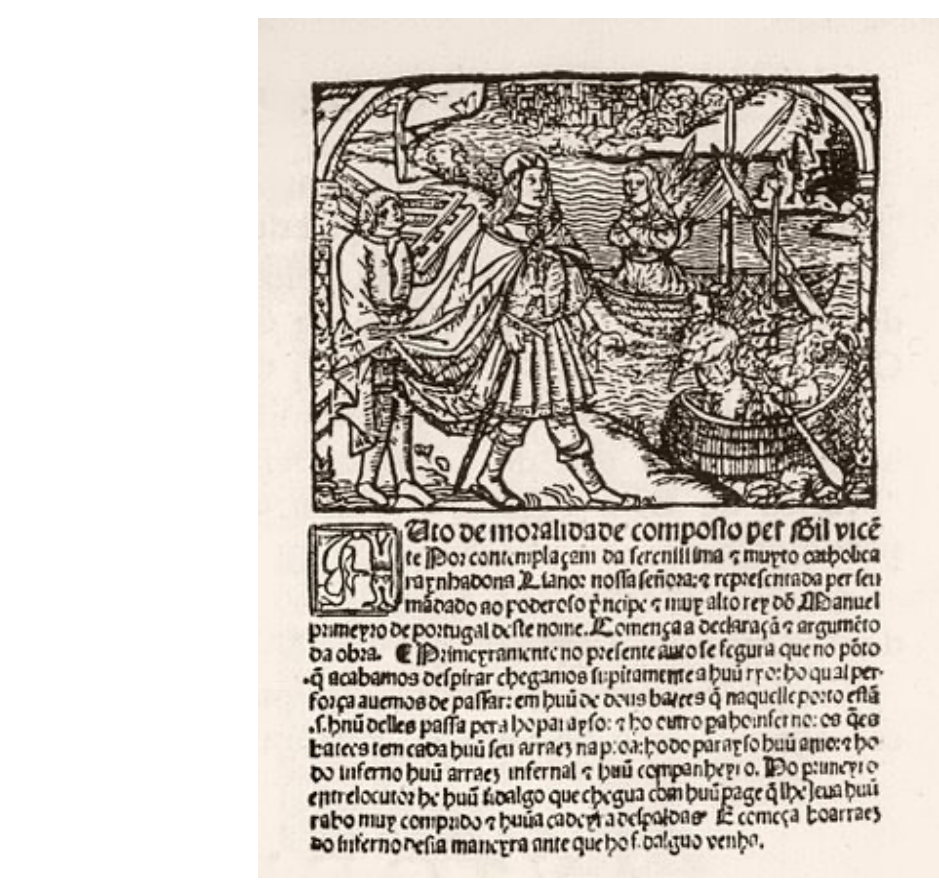

Figure 4: Book frontispiece of Auto da Moralidade - also known as Play of the Ship of Hell, from Gil Vicente, c. 1500. In Cruz, José Marques da, História da Literatura, Melhoramentos, São Paulo, 1939. Public domain.

https://pt.m.wikipedia.org/wiki/Ficheiro:Auto de Moralidade de Gil Vicente.jpg

and repelling smell of this raw low-cost vegetable suggests an identity transfer between the onion and its usual consumers, who release through pores, mouths and other body parts the scent of what they eat. That is also the case of the Villain, who feeds on garlic, leeks, bacon, bread and turnips, all of them examples of low-cost and common foodstuffs. The Master, in turn, eats delicacies such as hares, capons, and partridges. The flesh of the latter bird appears consistently in fiction narratives over the centuries as a product associated with high social strata. In the Auto da Serra da Estrela (Play of the Mountain of the Star) Gil Vicente mentions a hermit's dream of the privileges of a sophisticated man: dinners of partridge and lunches of wine and moxama (dried and salted fish, often tuna):

Aa cea $\&$ jantar perdiz, O almoço moxama, $\&$ vinho do seu matiz $[\ldots]^{3}$.

On the other hand, sardines were an abundant and cheap source of food, the sustenance of the less well-off (as they continued to be until the 20th century). Gil Vicente

\footnotetext{
${ }^{3}$ Gil Vicente, Tragicomedia Pastoril da Serra da Estrella. Four plays of Gil Vicente, 1963, p. 67. “On partridge would I soup and dine, / Of stockfish should my luncheon be / And of wine the very best [...]." (Translation by Aubrey Bell, from the initial 1920 Cambridge University Press edition.)
} 
includes them in the speech of the Villain, a lower-class character, who defends his social position in opposition to the Lord: "Porque com duas sardinhas, / Fico eu mais satisfeito, / Que vós com vosso desfeito, / Nem com Capões, nem galinhas, / Não nos fazem mais proveito". ${ }^{4}$

Depending on the political context of Portuguese history, eating certain foods could also pose serious problems for those who, for example, secretly professed the Jewish faith. The Fool, in his role of inconsequential initiator of the action in the Auto da Barca do Inferno (Play of the Ship of Hell) (1517), denounces the Jew ${ }^{5}$ through the practice of eating meat on 'Our Lord's Day', one of 70 days of the year when Christians were supposed to forego meat, replacing it with fish. The eating habits of the Jewish conversos (those who publicly renounced Judaism and professed Christianity) at that time helped the author to characterize them socially: they ate cakes (the excess of which caused diarrhea in Samuel), but also foods related to the East associated with Jews and Muslims, such as aubergines, cucumbers, carrots with fava beans, and spices such as cumin and saffron (Auto da Lusitânial Play of Lusitânia). These works by Gil Vicente are morality plays that caricature the Portuguese society of his time, particularly the customs of Lisbon residents.

\section{8th century - The Satirical Food}

The Portuguese literary world of the eighteenth century continued to favor social criticism through fictional narrative. The picaresque genre became popular in Portugal and was used to criticize social characteristics and habits. Irony and satire were also largely explored as means to understand society from a sociological and anthropological perspective, as can be seen in the set of humorous pamphlets by António Manuel Policarpo da Silva entitled $O$ piolho viajante, divididas as viagens em mil e uma carapuças (1821). ${ }^{6}$ In this work, he describes the adventures and reflections of a louse that goes through the heads of 72 types of Lisbon dwellers. This flying louse narrator goes through such disparate heads as those belonging to a gypsy, a philosopher, a judge, and an apothecary, and uses resources such as drinks and food to enliven the narrative and

\footnotetext{
${ }^{4}$ Gil Vicente, Obras Completas, 1979, p. 490. "Because with two sardines, / I am more satisfied, / Than you with your soft meat, / Neither with capons nor chickens, / Do not make us profit."

${ }_{5}^{5}$ Jewish conversos (converted to Catholicism). No one could be openly Jewish in Portugal after 1497 and the pogroms of 1506.

${ }^{6}$ António Manuel Policarpo da Silva, O piolho viajante. Divididas as viagens em mil e uma carapuças,

1973 [1821], Carapuça X.
} 
help characterize these social types. More appreciated by popular readers than by literati, this set of texts is a product of the time with a satirical vein that draws on every day, anecdotic and intimate details to captivate and entertain the audience. It has, though, an innovative psychological dimension as the texts are written in a highly reflexive and discursive manner. Nevertheless, as in the case of Gil Vicente's works, food remains associated with social types: the barber eats a clove of garlic and drinks a glass of brandy in the morning; the young men who work in a house of poor noblemen have barley coffee and the maid mackerel, and there was no money for dinner; the poor eat small, spiced sardines and bread and cheese, wishing that they could have plenty of wine like the rich; the sailor has his portion of water, wine and biscuits... It is also possible to perceive in this work the daily rhythm of an idle nobleman through mealtimes: he gets up from bed between 10:00 and 11:00 a.m., has lunch, plays card games until 4:00 p.m., finishes coffee at 5:00 p.m., combs, shaves, dresses to go out, gets into his carriage, makes social visits, goes to theaters, strolls in the square, spends the night in skirmishes and gambling, returns home between 3:00 and 4:00 a.m., and has supper before bed. Additionally, the author critically describes the adulterations that would be made to certain foodstuffs with the purpose of increasing the profits for those who sold them. To this end, barley is mixed with fava beans, chocolate with grease, sponge cake is made without eggs, and coffee is made from carob by the owner of a Lisbon tavern, where many go to have coffee with toast and talk while their family is hungry at home, without food, as observed by the narrating louse on the top of the owner's head. ${ }^{7}$

\section{Eça de Queirós (1845-1900) - The Sweeping Detail}

Social criticism continued to punctuate narrative fiction in the following century, with authors of reference in the literary medium systematically resorting to eating habits to emphasize characteristics and accentuate differences. Perhaps this was the century in which the clear perception of the "other" was most evident in all its manifestations, including literature. This was a time of several simultaneous and conflicting paths of development: some regarding the end of slavery and colonial independence; others privileging the exotic, the "authentic," "genuine", and untouched aspects of cultures. ${ }^{8}$

\footnotetext{
${ }^{7}$ Policarpo da Silva, O piolho viajante, op. cit., passim.

${ }^{8}$ The resurgent taste and reinterpretation of exoticism from European cultural perspectives in the $19^{\text {th }}$ century involved concerns with the perception and description of "otherness" and difference. See the critical
} 
Eça de Queirós was one of the authors who, in a realistic and descriptive style, used critical literary resources to articulate a way of seeing the world:

O caráter de uma raça pode ser deduzido simplesmente do seu método de assar a carne. Um lombo de vaca (...) faz compreender melhor as diferenças intelectuais destes povos do que o estudo das suas literaturas. ${ }^{9}$

The author refers to the fact that in Portugal the meat is a loin of veal roasted in the oven with all the seasonings until well cooked; in France the fat and skin cut out, tied, seasoned and cooked in the oven; and in England, it goes to the oven without preparation, to be consumed raw inside and toasted on the outside. Mustard, salt and pepper are on the table for each person to season it to their liking. ${ }^{10}$ The preferences in food preparation and tasting were regarded as elements deeply rooted in historical and cultural habits and contingencies. Food and drink continued their path as social and character metaphors in identity creation and maintenance, and as extremely useful literary resources.

The large influence of French culture on the Portuguese elites of the nineteenth century - which lasted until the mid-twentieth - manifests itself, for example, in the menu at a meal for Lisbon notables at the Universal Hotel in the posh neighborhood of Chiado:

\section{HUÎTRES}

HORS-D'EUVRE

POTAGES:

Julienne, Tapioca Grécy

POISSON:

Turbot, sauce hollandaise

ENTRÉES:

Escalope, de veau à la Macédoine Suprême de volaille à la Melchior Jambons d'York aux épinards Filets mignons à la Saavedrá

GIBIER: Perdreaux rôtis à la crapaudine

ENTREMETS:

Charlotte Russe Dartois doré

works on the subject: Edward Said, Edward, Orientalism, 1978; Victor Segalen, Essay on Exoticism: An Aesthetics of Diversity, 2002; Graham Huggan, The Postcolonial Exotic: Marketing the Margins, 2001.

${ }^{9}$ Eça Queirós, Textos de Imprensa IV. Da Gazeta de Noticias, 2002, p. 316. "The character of a race can be deduced simply by its method of roasting the meat. A cow's loin [...] prepared in Portugal, in France, or in England is more helpful to understand the intellectual differences of these three peoples than the study of their literatures."

${ }^{10}$ Maria Antónia Goes, À mesa com Eça de Queirós, 2004, p. 121. 


\section{GLACES, DESSERT}

VINS:

Bucelas, Colares, St. Julien, Champagne, Porto

CAFÉ - LIQUEURS. ${ }^{11}$

The menu differs markedly from what would be more typically eaten in the countryside, as described in $O$ crime do padre Amaro (The Crime of Father Amaro): a priest's lunch at the Abbot of Cortegaça's house included chicken broth, blood stew, stuffed capon, green beans, sweet rice and nuts, served on a table on scattered small plates with black olives and scarlet peppers. The drinks are Bairrada and Oporto wines and coffee. ${ }^{12}$ Rural and urban elites of the nineteenth century differed greatly in gastronomic culture, with urban ones showing a great predilection for prevalent tastes among the parallel social classes of other European countries, and especially France. Another clear manifestation of this tendency was the number of cookbooks written and/ or compiled by notables, aristocrats, and owners of prestigious urban restaurants displaying French recipes or adaptations of established Portuguese ones to the presumably French taste.

Ramalho Ortigão, friend and contemporary of Eça de Queirós, once wrote that "the way one cooks marks the index of civilization of a people," and Eça himself, in the chronicle published in the Rio de Janeiro Gazette in 1893 - Cozinha Arqueológica (Archaeological Cuisine) - wrote that cooking is one of the manifestations that "best reveal[s] the genius of a race," and that "the table has always been one of the strongest, if not the strongest foundation of human societies." 13 These assertions must be appreciated in the light of the political and cultural western context at the end of the $19^{\text {th }}$ century. The search and reinvigoration of "the authentic," "the unspoiled" - usually found in remote and rural areas - was a quest undertaken by members of the cultural elite of a wide range of western countries, in order to build nationalist identities rooted in the hearts of the nation's purest inhabitants. This reflects on a number of Eça's works, particularly his last novel, A Cidade e as Serras.

Gastronomic scenes, while appearing as hyper-realistic descriptions, are also endowed with important diegetic and ideological functions: they structure the moral and material environment, enhance the figuration of the characters, direct the development of

\footnotetext{
${ }^{11}$ Eça de Queirós, A Capital, 2003 [1925], p. 160.

${ }^{12}$ Ibid., p. 32.

${ }^{13}$ Ana Teresa Peixinho, "Food aesthetics: culinary notes on the work of Eça de Queirós", 2016, p. 200201.
} 
narratives and provide criticism and satire. The kitchen is a structuring pillar of the narrative universe of Eça's novels, ${ }^{14}$ being simultaneously a physical and symbolic place where Portuguese society performs itself.

The way verbs are used, the type of delicacies described, and a wide range of adjectives and stylistic choices help to stimulate the visual imagination regarding food consumption. The verbs are particularly useful as resources in this context for they transmit highly graphic mental images of the eating actions - "devour" croquettes, "bite with your teeth" into a fig, "chew" a steak - which are heavily charged with conceptions about education, economic and class status, health, and cultural context. The adaptation of the vocabulary to the settings as well as to the profiles of the characters, precisely accentuates differences, ${ }^{15}$ thereby creating alterity. The absolute other emerges from blatant considerations such as the one in a letter Queirós addressed to his friend Bernardo, the Count of Arnoso, in 1885, from Bristol. In this city, Queirós complains of living in a society "in which everything is unpleasant to him - from the narrow way of thinking to the indecent way of baking vegetables."16

The contrasts between abundance and scarcity as elements that characterize the Portuguese society of the time are also recurrent narrative strategies in Queirós's work. As a provincial journalist, he relates accurate and useful information on agricultural and commercial issues, so that to read some of his writings is to gain an idea of the cost of wine, olive oil and bacon, of two and a half arrays of beef, of pork butter - that is to say, food of daily consumption, typical of the diet of the Alentejo inhabitants at that time. On the other hand, the journalist positions himself as an advocate of the oppressed, asked to make immense sacrifices in the face of the high cost of living, during an acute financial and economic crisis. ${ }^{17}$ This constant confrontation between abundance and deprivation tightly associated with class cleavage in Queirós's fictional narratives is an invaluable resource to help configure alterity. The author resorts to amounts and types of food to inform readers about the psychology and context of characters, emphasizing opposites to mark his descriptions. Thus, in the midst of a hearty repast, at the Abbot of the Cortegaça's home - who "passava por ser o melhor cozinheiro da diocese"18 - the clergy of Leiria

\footnotetext{
${ }^{14}$ Ana Teresa Peixinho, idem.

${ }^{15}$ Ana Teresa Peixinho, ibid., p. 203

${ }^{16}$ Ibid., p. 204.

${ }^{17}$ Ibid., p. 205.

${ }^{18}$ Eça de Queirós, O Crime do Padre Amaro, 2000, p. 75. "[...] went on to be the best cook in the diocese." It is worth saying that clergy members used to eat - and even cook, as in the case mentioned - abundantly and luxuriously due to the habitual gifts of every kind of foodstuffs by their parishioners. The best parts, or
} 
delight around a beautiful stuffed capon, when a beggar comes to beg. The latter is only entitled to half a dried corn bread, while the priests faintly comment on the poverty of the region, gorging themselves with a delicacy:

- Muita pobreza por aqui, muita pobreza! - dizia o bom abade. - Ó Dias, mais este bocadinho de asa! - Muita pobreza, mas muita preguiça - considerou duramente o padre Natário. Em muitas fazendas sabia ele que havia falta de jornaleiros, e viam-se marmanjos, rijos como pinheiros, a choramingar padres-nossos pelas portas. - Súcia de mariolas! - resumiu. - Deixe lá, padre Natário, deixe lá! - disse o abade. - Olhe que há pobreza deveras. Por aqui há famílias, homem, mulher e cinco filhos, que dormem no chão como porcos e não comem senão ervas. - Então que diabo querias tu que eles comessem? - exclamou o cónego Dias lambendo os dedos depois de ter esburgado a asa do capão. - Querias que comessem peru? Cada um como quem é! $!^{19}$

This excerpt of $O$ crime do padre Amaro (The Crime of Father Amaro) is constructed in a manner that sharply reveals how a privileged class regards another and finds ways of justifying profound and evident inequalities. The conspicuous barriers separating social classes of the time configure themselves as insurmountable by the words and actions of the characters. In O primo Basílio (Cousin Bazilio), Queirós depicts housemaids that are almost always underfed - and are surely not allowed to taste their master's delicacies. In a revealing episode regarding the keys to the larder jealously guarded by Luisa and coveted by Juliana, the latter, during one of her mistress's distractions, takes the opportunity to "beber um trago de bom vinho, engolir dois ladrilhos de marmelada...". ${ }^{20}$ This illustration of discontent about the way Juliana is treated by her employer through food episodes ends up being a key to the narrative developed by Queirós, in which the maid's dissatisfaction is an agent of her mistress's dramatic fall.

On one of the walks through his homestead in the Douro, the cosmopolitan Jacinto is surprised when he realizes that the people, whose culinary art has dazzled him so much, are starving and undernourished, with only a crust of dry bread. These brief

even the whole animal, of stock killed to feed farmers' households was reserved to priests and doctors, as well as the best butter, cream, milk, vegetables, fruits, sweets, and delicacies purposely made as offerings. ${ }^{19}$ Eça de Queirós, O Crime do Padre Amaro, 2000, p. 205-207. "- Too much poverty here, too much poverty!, said the good abbot. - Too much poverty, but too much laziness, Father Natario said sternly. - I knew that there was a shortage of hired laborers on many farms, but there were men, tough as pine-trees, begging the doors. - Idle men!, he summed up. - Let it go, Father Natario!, said the abbot. - Look, there's poverty. Around here there are families, a man, a woman and five children, who sleep on the floor like pigs and eat only herbs. - Then what the devil did you want them to eat?, exclaimed canon Dias, licking his fingers after shedding the capon's wing. - Did you want them to eat turkey? Each one as who he is!"

${ }^{20}$ Eça de Queirós, O Primo Basílio, p. 75. “ [...] drink a drink of good wine and swallow two pieces of quince jam." 
notes illustrate the contrast between opulence and scarcity, the relative price of each, and how food is used to emphasize the social imbalances that disturbed the writer. ${ }^{21}$

Exotic alterity is another way to convey otherness in Queirós's works. Food and drink are priceless cultural evidence of dramatic - and frequently misunderstood or feared - differences. In the chronicles reporting on the great Universal Exhibition in Paris (1867) written for the Distrito de Évora (District of Évora) newspaper, the exoticism of the "suspeitosa cozinha de proveniência asiática"22 is highlighted:

Quem responderá - pergunta o cronista - pela veracidade e frescura dos ninhos de Salangana? Não estará alterado o molho de bichos-de-conta pisados? Dizem-nos que as frituras de gafanhotos são tentadoras, mas que a conserva de lagartas de couve pouco tem agradado." 23

Aware of the food taboos and knowing how they might generate surprise in the readers, the selected menus of oriental cuisine are described with such a realism that it will lead the most unsuspecting reader to believe that Queirós is indeed in Paris visiting the Universal Exhibition. It is astonishing how, without leaving Évora and not having set foot in the Great Exhibition, the journalist can so heartily follow the report of the event and comment on the exotic oriental snacks, so different from the traditional dishes of the national diet. ${ }^{24} \mathrm{~A}$ highly descriptive narrative vividly evokes the scenes and engages the reader, and Queirós uses it to dazzle with cultural oddity. The fascination with the absolute cultural “other" was also a tendency in $19^{\text {th }}$-century Europe, and Queirós's literary works reflect how Portuguese society tended to regard and understand the unfamiliar. In $O$ Mandarim (The Mandarin) (1880) the exotic notations of the table abound, with descriptions of the decoration of the rooms and the eccentricity of bits of delicacies. ${ }^{25}$

Nessa manhã - conta o narrador - em honra da minha nova encarnação, havia um almoço chinês. Que gentis guardanapos de papel de seda escarlate, com monstros fabulosos desenhados a negro! O serviço começou por ostras de Ning Pó. Exímias! Absorvi duas dúzias com um intenso regalo chinês. Depois vieram deliciosas febras de barbatana de tubarão, olhos de carneiro com picado de alho, um prato de nenúfares em calda de açúcar, laranjas de Cantão, e enfim o arroz sacramental, o arroz dos Avós... Delicado repasto, regado largamente de excelente vinho de Chão-Chigne! E,

\footnotetext{
${ }^{21}$ Ana Teresa Peixinho, op. cit., p. 206.

${ }^{22}$ Eça de Queirós, Páginas de Jornalismo, 1981, p. 215. "suspicious kitchen of Asian provenance."

${ }^{23}$ Eça de Queirós, Páginas de Jornalismo, 1981, p. 215. "Who will answer - asks the chronicler - for the veracity and freshness of the nests of Salangana? The gravy of woodlouse will not be corrupted? We are told that the locust fritters are tempting, but that the preserve of little cabbage caterpillars has not pleased."

${ }^{24}$ Ana Teresa Peixinho, op. cit., p. 207.

${ }^{25}$ Ibid., p. 207-208.
} 


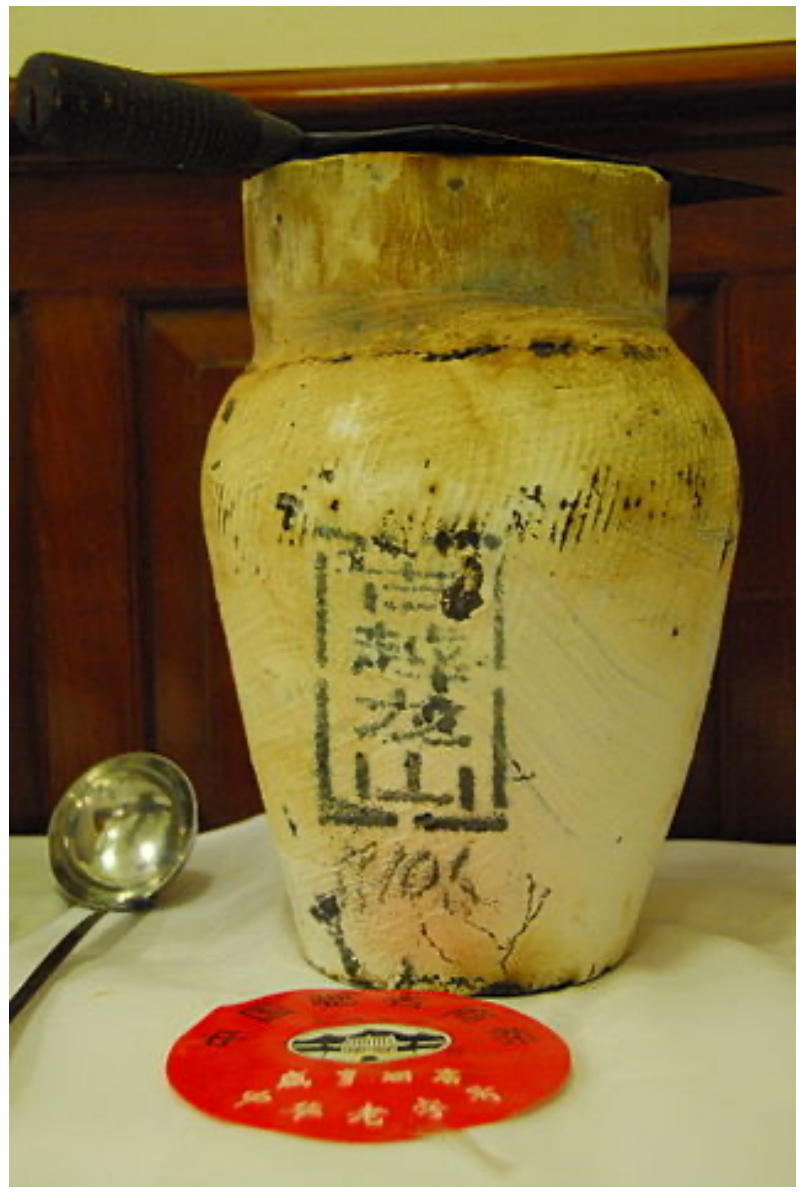

Figure 5 : Shaoxing wine, one of the most famous varieties of huanaiiu, or traditional Chinese wines, fermented from rice. It originates from the region of Shaoxing, in the Zheijiang province of eastern China. CC BY-SA 2.0.

https://en.wikipedia.org/wiki/Shaoxing wine\#/media/File:ShaoxingwinefromXianHengInn.jpg

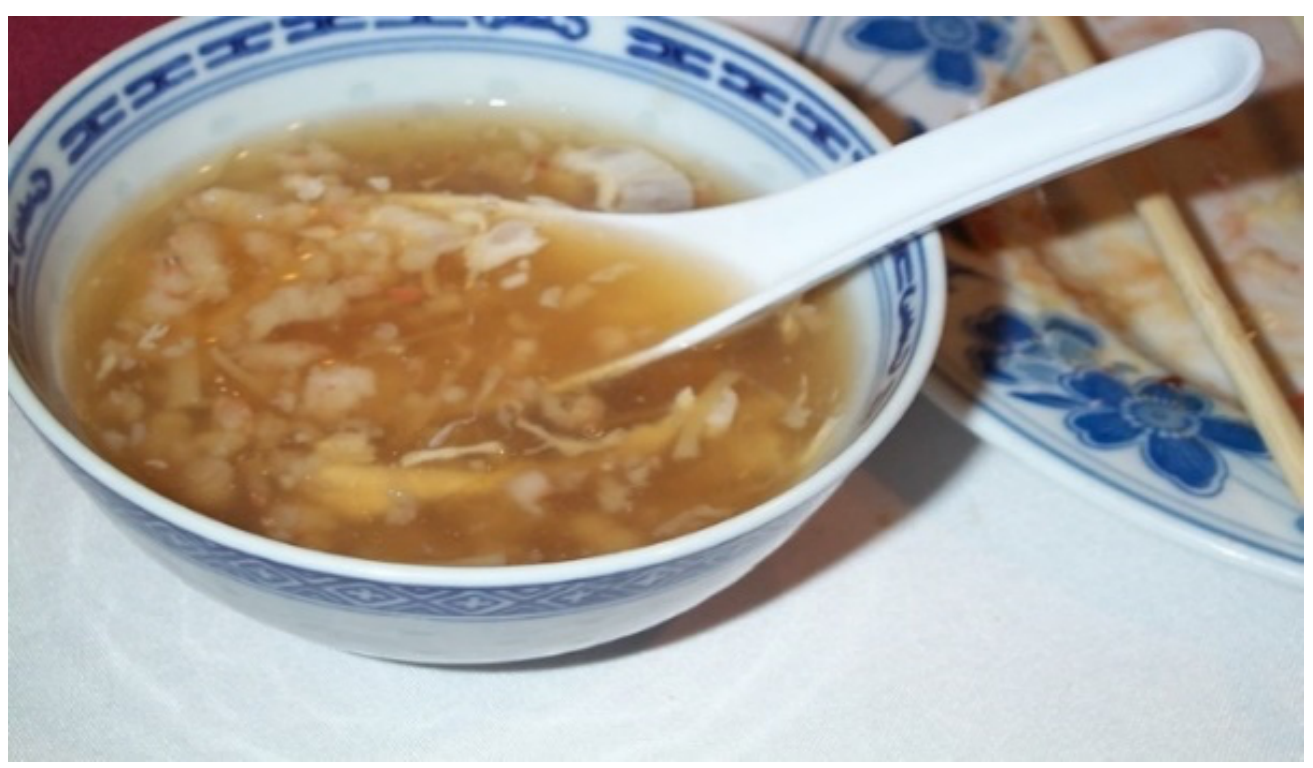

Figure 6: Salangana - mossy-nest swiftlet, whose nests made of saliva and algae are edible in form of soup. CC BT-SA 2.0. https://pt.wikipedia.org/wiki/Ficheiro:Bird\%27s Nest soup.jpg

Topiques, Études satoriennes, 5, 2020, Le Boire et le manger, https://journals.uvic.ca/index.php/sator/index 
por fim, com que gozo recebi a minha taça de água a ferver, onde deitei uma pitada de folhas de chá imperial, da primeira colheita de março, colheita única, que é celebrada com um rito santo pelas mãos puras de virgens!... ${ }^{26}$

Food is a means of gender and class criticism as well for Eça de Queirós, who always poignantly observes the habits in his social environment. In a text published in March 1872 on female education, the writer points to eating as one of the vectors that greatly contributes to the fragility of character found among the young bourgeois women of Lisbon:

A menina solteira! Vejamos o tipo geral de Lisboa. É um ser magrito, pálido, metido dentro de um vestido de grande puff, com um penteado laborioso e espesso, e movendo os passinhos numa tal fadiga que mal se compreende como poderá jamais chegar ao alto do Chiado e da vida. ${ }^{27}$

The sickly frailty, the result of a conservative, distorted and anemic education, is also the result of an unbalanced diet. Gluttony is, like fashion, readings and the household, one of those aspects responsible for the fragility of the Portuguese women from the urban bourgeoisie. ${ }^{28}$

[estas raparigas] não comem: é raro ver uma menina alimentar-se de peixe, carne e vinho. Comem doce e alface. Jantam sobremesas. A gulodice do açúcar, dos bolos, das natas, é uma perpétua desnutrição. [...] Lisboa é uma cidade doceira, como Paris é uma cidade intelectual. Paris cria a ideia, Lisboa o pastel. Daí a grande quantidade de doenças de estômago e de maus dentes. A deterioração pelo doce começa aos quatro anos. O sangue alimentado a massa, ovos, natas, dá estes corpos débeis e estas almas amolecidas. ${ }^{29}$

\footnotetext{
${ }^{26}$ Eça de Queirós, O Mandarim, 1992, p. 141. "This morning, Chinese lunch. Such nice napkins of scarlet silk paper, with fabulous black monsters! The service started with Ning Po oysters. The best! I absorbed two dozen with an intense Chinese delight. Afterwards delicious shark fin feathers, minced garlic eyes, a bowl of watermelon syrups, oranges from Canton, and finally the rice, the Grandparents' rice... Delicate repast, largely watered by excellent Shaoxing wine! And finally, with what joy I received my cup of boiling water, where I laid a pinch of imperial tea leaves, the first harvest of March, a single harvest, which is celebrated with a holy rite by the pure hands of virgins!"

${ }^{27}$ Eça de Queirós, O Primo Basilio, s. d., p. 325. "The single girl! Let's look at the general type of Lisbon. She is a pale, skinny being, tucked into a big puff dress, with a thick, laborious hairstyle, and moving her steps in such a fatigue that she can barely grasp both the top of Chiado and of life."

${ }^{28}$ Ana Teresa Peixinho, op. cit., p. 209.

${ }^{29}$ Eça de Queirós, $O$ Primo Basílio, p. 325. "[These girls] do not eat: it is rare to see a girl eating fish, meat and wine. They eat sweet and lettuce. They serve desserts. The gluttony of sugar, cakes, and cream is a perpetual malnutrition. [...] Lisbon is a sweet city, as Paris is an intellectual one. Paris creates the idea, Lisbon the cake. Hence the great number of diseases of the stomach and of bad teeth. Deterioration by candy begins at age four. Blood fed by dough, eggs and cream produce these weak bodies and softened souls."
} 
Queirós's sharp comments illustrate the contrast between the misuse of the bounty at the disposal of these idle, privileged women and what is perceived as the healthier and more natural eating of the working rural girls, aligned with the previously mentioned search for the purest and most authentic spirit of a nation built by means of healthy meaningful work.

Pretext for the moral criticism of social dissolution, the national confectionery here is a symbol of decay that contrasts with the "City of Lights," the center of this civilized Europe. In Queirós's writings, table scenes, appetites and food uses are invaluable resources for the composition and figuration of the characters, outlining their personality and indicating addictions and behaviors. It is also by describing the storefront of a Lisbon confectionery that the narrator of this novel reveals the decadence of the middle bourgeoisie of the Portuguese kingdom. The characters Sebastião and Julião from O Primo Basilio, worried about Luisa's reputation and the threat posed by cousin Bazilio's assiduous visits to her home, meet to discuss the matter. The subject of the dialogue is paralleled with an overwhelming description of the showcase in front of which the characters stand and which displays a decadent socio-moral aesthetic space:

Estavam parados ao pé da confeitaria. Na vidraça, por trás deles, emprateleirava- se uma exposição de garrafas de malvasia com os seus letreiros muito coloridos, transparências avermelhadas de gelatinas, amarelidões enjoativas de doces de ovos, e queques de um castanho-escuro tendo espetados cravos tristes de papel branco ou cor-de-rosa. Velhas natas lívidas amolentavam-se no oco dos folhados; ladrilhos grossos de marmelada esbeiçavam-se ao calor; as empadinhas de marisco aglomeravam as suas crostas ressequidas. E no centro, muito proeminente numa travessa, enroscava-se uma lampreia de ovos medonha e bojuda, com o ventre de um amarelo ascoroso, o dorso malhado de arabescos de açúcar, a boca escancarada; na sua cabeça grossa esbugalhavam-se dois horríveis olhos de chocolates; os seus dentes de amêndoa ferravam-se numa tangerina de chila; e em torno do monstro espapado moscas esvoaçavam. ${ }^{30}$

This is an extremely successful literary strategy, where the rotten morals of the characters are conveyed to the reader in two different dimensions: the words on one side, and the more triggering graphic, visceral and decadent food descriptions on the other.

\footnotetext{
${ }^{30}$ Eça de Queirós, ibid. p. 323. "They were standing at the foot of the confectionery. On the glass pane, behind them, there was an exhibition of Malvasia bottles with very colorful signs, reddish transparencies of jelly, cloying candies of egg yolks and muffins of a dark brown with spiked sad white carnations or pink. Old livid creams were dying in the hollow of the puffs; thick marmalade tiles stood out in the heat; the seafood pies crowded their parched crusts. And in the center, very prominent on a platter, stood a hideous and bulky lamprey of eggs, with the belly of a repulsing yellow, the lapped rosy arabesques of sugar, the open mouth; two horrible eyes of chocolates gaped in his thick head; his almond-like teeth were pierced in a cherry mandarin; and fluttering monster flies fluttered around."
} 


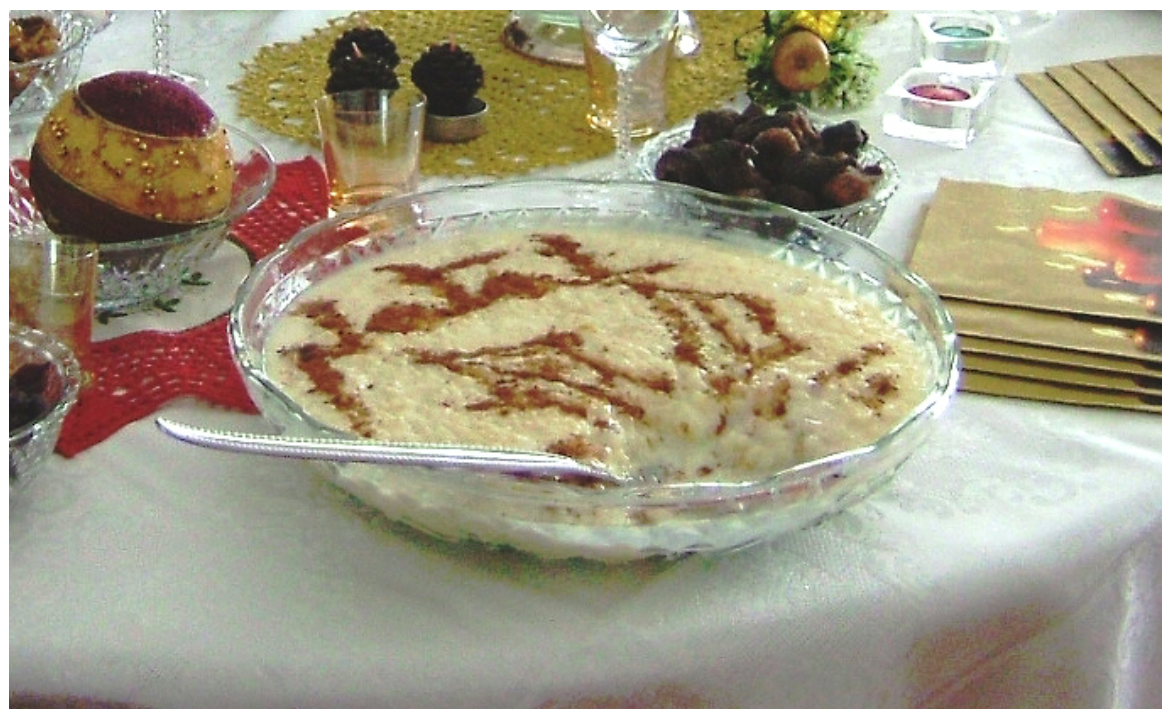

Figure 7: Arroz doce - sweet rice, Portuguese traditional style. CC BY-SA 3.0. https://pt.wikipedia.org/wiki/Arroz-doce\#/media/Ficheiro:ArrozDoce.jpg

On the other hand, Portuguese sweets win over the sophisticated Jacinto and the eccentric Fradique, from the peach jams to the sweet rice - perhaps the most cited dessert in Queirós's fiction.

The author illustrates aspects of national gastronomy as a positive identity brand, as opposed to the sophistication of haute cuisine française, imported as fashion. There is a very expressive point in A Cidade e as Serras of this binomial characteristic of Queirós's writing: the antithesis between the genuine and the distorted copy. In this story, the character Zé Fernandes decides to order from the illustrious French cook of the ChampsElysees a beautiful platter of sweet rice, made the Portuguese way, to delight Jacinto on his birthday. The outcome is not expected:

[...] mas quando o arroz-doce apareceu triunfalmente, que vexame! Era um prato monumental, de grande arte! $\mathrm{O}$ arroz, maciço, moldado em forma de pirâmide do Egito, emergia duma calda de cereja, e desaparecia sob os frutos secos que o revestiam até ao cimo onde se equilibrava uma coroa de Conde feita de chocolate e gomos de tangerina gelada! E as iniciais, a data, tão lindas e graves na canela ingénua, vinham traçadas nas bordas da travessa com violetas pralinadas! Repelimos, num mudo horror, o prato acanalhado. E Jacinto, erguendo o copo de champanhe, murmurou como num funeral pagão: - Ad Manes, aos nossos mortos! ${ }^{31}$

\footnotetext{
${ }^{31}$ Eça de Queirós, The City and The Mountains, 1994, p. 96. "But what a vexation when 'sweet rice' finally appeared! It was a monumental work of art, no doubt. The rice was molded into the shape of a pyramid of Egypt. It emerged from a thick sauce of cherry juice and disappeared in layers of dried fruit which coated it on all sides to the summit, on which was balanced the Crown of the Counts of Tormes in chocolate, plugged with frozen quarters of tangerine! And the initials which I had wanted to be traced in simple cinnamon on the rice itself, had been worked round the edge of the dish in candied violets. We rejected it in silent horror. Jacinto raising his cup of champagne as if at a pagan funeral, drank solemnly: "Ad Manes, to the shades of our Dead!" (Translation quoted from Roy Campbell English edition.)
} 
It is a question of valuing authenticity rather than the inadequate imitation of French imports. It is because of the excellence of the national cuisine that the snobbish and cosmopolitan Jacinto is seduced by the Portuguese land. The main character of The City and the Mountains, saturated with the progress and sophistication of his Parisian life on the Avenue of the Champs-Elysées, is conquered by Portuguese rurality largely through the consumption of food and drink. Since arriving in his native country, Jacinto - who until then considered it unacceptable to live in an underdeveloped world like this - is constantly confronted with the purity of the landscape, the purity of the air, the beauty of the Douro hills and, of course, the flavors and aromas of the national gastronomy. ${ }^{32}$ His initial resistance, typical of those who have become accustomed to sophisticated French cuisine, is very quickly overcome since the protagonist lets himself become enchanted by the smells, the colors, and the flavors of old Portugal's dishes. It is a return to the origins, to the decontaminated and natural world of a typical Portugal, where progress has not yet corrupted habits or traditions. This quest for authenticity is a cultural outcome of the Industrial Revolution, exacerbated by the sensation that the world is in the midst of breathtaking change with a future not easy to predict. This is the context for the tremendous rural dinner prepared by Melchior, a narrative episode proposed as an initiation ritual during which Jacinto begins to be conquered by his stomach: ${ }^{33}$

Na mesa, encostada ao muro denegrido, sulcado pelo fumo das candeias, sobre uma toalha de estopa, duas velas de sebo em castiçais de lata alumiavam grossos pratos de louça amarela, ladeados por colheres de estanho e por garfos de ferro. Os copos, de um vidro espesso, conservavam a sombra roxa do vinho que neles passara em fartos anos de fartas vindimas. A malga de barro, atestada de azeitonas pretas, contentaria Diógenes. Espetado na côdea de um imenso pão reluzia um facalhão. [...] Jacinto ocupou a sede ancestral - e durante momentos (de esgazeada ansiedade para o caseiro excelente) esfregou energicamente com a ponta da toalha, o garfo negro, a fusca colher de estanho. Depois, desconfiado, provou o caldo, que era de galinha e rescendia. Provou - e levantou para mim, seu camarada de misérias, uns olhos que brilharam, surpreendidos. Tornou a sorver uma colherada mais cheia, mais considerada. E sorriu, com espanto. - Está bom! Estava precioso. Tinha fígado e tinha moela: o seu perfume enternecia: três vezes, fervorosamente, ataquei caldo. Também lá volto! - exclamava Jacinto com uma convicção imensa. - É que estou com uma fome... Santo Deus! Há anos que não sinto esta fome. ${ }^{34}$

\footnotetext{
${ }^{32}$ Ana Teresa Peixinho, op. cit., p. 212.

${ }^{33}$ Ana Teresa Peixinho, op. cit., p. 213.

${ }^{34}$ Eça de Queirós, The City and The Mountains, p. 126-127. "On the table against the blackened wall, which was stained with the soot of oil-lamps, on a tablecloth of sacking, two tallow candles in tin candlesticks illumined huge dishes of yellow earthenware, flanked with tin spoons and iron forks. The glasses of great thickness still bore the red shade of all the wine which had passed in and out of them during many years of bumper vintages. The clay bowl which was heaped with black olives would have delighted Diogenes. Struck into the crust of an immense loaf gleamed a huge knife like a scythe blade. [...] Jacinto took the ancestral seat and for moments (moments of terrible anxiety for the poor head-farmhand)
} 
This episode alludes in a not-so-subtle way to eating as a status performance instead of an action destined to fuel the body and, if possible, please the senses without distorting wise and respectful cooking practices with baroque mannerisms. The imitation of the "other" (here, French culinary habits) is criticized by using the opposition between country and city habits of food preparation and consumption.

Portuguese gastronomy is fostered as a symbolic element in Queirós's fiction, with a clear ideological sense: the valorization of the rural country and the resistance to culinary models coming from abroad (mainly from Paris) which were adopted by the established bourgeoisie in their social/ public life. In his short narratives Queirós uses food to develop relevant narrative meanings, namely thematic isotopies.

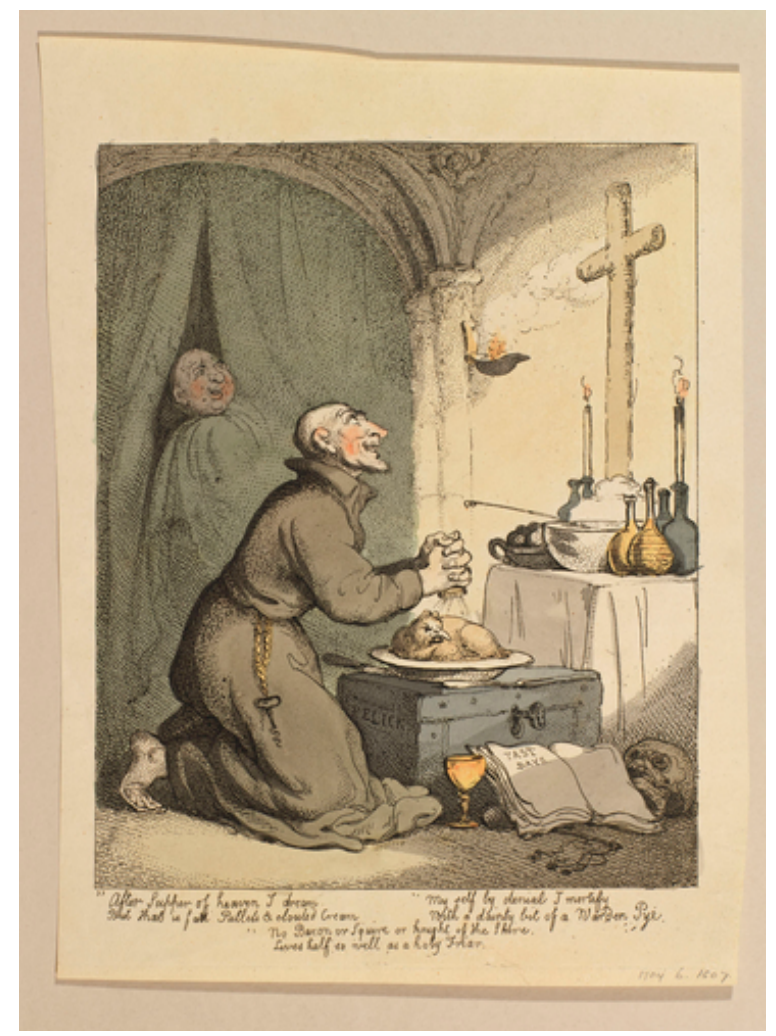

Figure 8: Thomas Rowaldson, The Holy Friar, 1807. The Metropolitan Museum of Art. Public domain. https://www.metmuseum.org/art/collection/search/742830n

energetically rubbed the black fork and the tarnished spoon with the corner of the tablecloth. Then, very suspiciously, he tasted the soup, which was of chicken, and smelt very good. He tasted it and raised to me (his comrade in hardships) two eyes that shone with delighted surprise. He tasted a bigger spoonful and considered the result for a longer time. He smiled, and said, in amazement: "It was good! It was delicious. It contained liver and gizzard. Its perfume filled one with tenderness: three times I attacked that soup with fervor. - I am also having another, - exclaimed Jacinto, with immense conviction. - I'm still very hungry... Good God! It's years since I felt such hunger." (Translation quoted from Roy Campbell English edition.)

${ }^{34}$ Eça de Queirós, "Frei Genebro" s.d., p. 111 
The loose morals of the Catholic Church representatives and their guiltless changing of preached principles when it suited their interests were also targeted by Queirós's pen. In his 1884 Friar Genebro, the capital sin was declared to be gluttony: the friar smeared his virtuous life to satisfy the gluttonous desire of a dying hermit who wanted a pork loaf. "Pecado? Não, certamente! Aquele que, por tortura, recusa ao seu corpo um contentamento honeste, desagrada ao senhor". ${ }^{35}$ The good friar, he argues, ought not to hesitate to satisfy the appetite of his dying friend by plucking in cold blood the leg of a living piglet, which lay on the ground in agony.

- Já vai alourando o porquinho, irmão Egídio! A pele já tosta, meu santo! Entrou enfim na choça, triunfalmente, com o assado que fumegava e rescendia, cercado de frescas folhas de alface. Ternamente, ajudou a sentar o velho, que tremia e se babava de gula. ${ }^{36}$

Although it is metaphorical in this tale, gluttony as a capital sin is essentially caricatured in Queirós through the construction of particular literary types. ${ }^{37}$ No Queirosian priest is acquitted of this sin, which is usually revealed by a prominent belly and by certain greedy tics. The abbot of the Cortegaça is presented in O Crime do Padre Amaro as someone who "passava por ser o melhor cozinheiro da diocese", ${ }^{38}$ a title that was attributed to him thanks to his famous game cooked in blood.

O excelente abade estava escarlate de satisfação. Era, como dizia o senhor chantre, um divino artista! Lera todos os "Cozinheiros Completos", sabia inúmeras receitas; era inventivo - e, como ele afirmava dando marteladinhas no crânio, "tinha-lhe saído muito petisco daquela cachimónia!" Vivia tão absorvido pela sua "arte" que lhe acontecia, nos sermões de domingo, dar aos fiéis ajoelhados para receberem a palavra de Deus, conselhos sobre o bacalhau guisado ou sobre os condimentos do sarrabulho. E ali vivia feliz, com a sua velha Gertrudes, de muito bom paladar também, com o seu quintal de ricos legumes, sentindo uma só ambição na vida - ter um dia a jantar o bispo! ${ }^{39}$

\footnotetext{
${ }^{35}$ Eça de Queirós, idem. "Sin? No, certainly! He who, by torture, refuses to his body an honest contentment, displeases to the Lord."

${ }^{36}$ Idem. "- The little piglet is already roasting, Brother Egídio! The skin is already toasted, my saint! Finally, he entered the hut, triumphantly, with the roast that was smoking and roasting, surrounded by fresh leaves of lettuce. Tenderly, he helped the old man to seat, who trembled and drooled in gluttony."

${ }^{37}$ Ana Teresa Peixinho, op. cit., p. 214.

${ }^{38}$ Eça de Queirós, O Crime do Padre Amaro, p. 110. " [...happened to be the best cook of the diocese."

${ }^{39}$ Eça de Queirós, O Crime do Padre Amaro, p. 111-112. "The fine abbot was scarlet with satisfaction. It was, as the lord said, a divine artist! He had read all the 'Complete Cooks', he knew innumerable recipes and was inventive. He was so absorbed in his 'art' that in his Sunday sermons he gave the kneeling faithful who received the word of God, advice on how to stew cod or to season sarrabulho [stew made of pig's curdled blood]. He lived there happily, with his old Gertrude, with his orchard of rich vegetables, feeling a single ambition in life - to dine someday with the bishop!"
} 
The frequent link between food lust and priesthood in Portuguese literature is also due to the fact that clergy members were actually treated to the best and most exquisite foodstuffs by parishioners who were thankful for their assistance in various matters of material and spiritual life. The satirical approach, a classical way to criticize spheres of power in society and to expose contradictions and problems, was widely used by a vitriolic author such as Eça de Queirós. Gluttony is also an allusion to sexual frustrations / compensations associated with clergy members. As a result, the author uses this food and drink metaphor to characterize other figures such as the spinster. The Viscountess of Runa in Os Maias "Parecia assim mais gorda, toda acaçapada na cadeira, silenciosa, comendo sempre; e, a cada golo de Bucelas, refrescava-se languidamente com o seu leque negro e lantejoulado". ${ }^{40}$ Felicidade, a female character from O Primo Basílio and a frustrated spinster, is presented as "very well nourished, round, which, despite suffering from dyspepsia, does not resist egg candy and ice cream." 41 The maid Juliana is described from her appearance in the novel as gluttonous and having a sweet tooth, nourishing "an unsatisfied desire to eat, of snacks, of desserts." ${ }^{2}$ The acts of compulsive eating and drinking illustrate the psychological imbalance compensated by the ingestion of pleasurable treats that give an immediate yet transient sensation of happiness. The ephemerality of the sensations caused by these gastronomic events incentivizes compulsivity, the unending repetition of ingestion - made possible usually by the social and economic strata of the characters. Like a playwright, Queirós outlines identities by creating sharp contrasts between the actors, using the notion of the dramatic "other" to paint vivid portraits. Spiritual poverty, laziness, greed, lust and ignorance created by poor education and badly oriented religious teachings are transposed into food by the author and convey his opinion of society and of the diverse individuals and classes that so very often share a table - as in the case of the omnipresence of clergyman at bourgeois homes. These functions are reinforced by the realistic, highly descriptive style designed to transpose the reader to the set of action, for which Queirós became known.

The scene of the characters at the table is intersected by the conversations and themes, with different food items making their entrances - from soup to dessert - and Queirós details suggestive descriptions of dishes, food, drinks, the delightful and

\footnotetext{
${ }^{40}$ Eça de Queirós, Os Maias. Episódios da vida romântica, p. 45. "[...] seemed fatter, all bent in the chair, silent, always eating; and, with each sip of Bucelas wine, she refreshed herself languidly with her large black and dinged fan."

${ }^{41}$ Eça de Queirós, O Primo Basílio, p. 111-112.

${ }^{42}$ Ana Teresa Peixinho, op. cit. p. 215.
} 


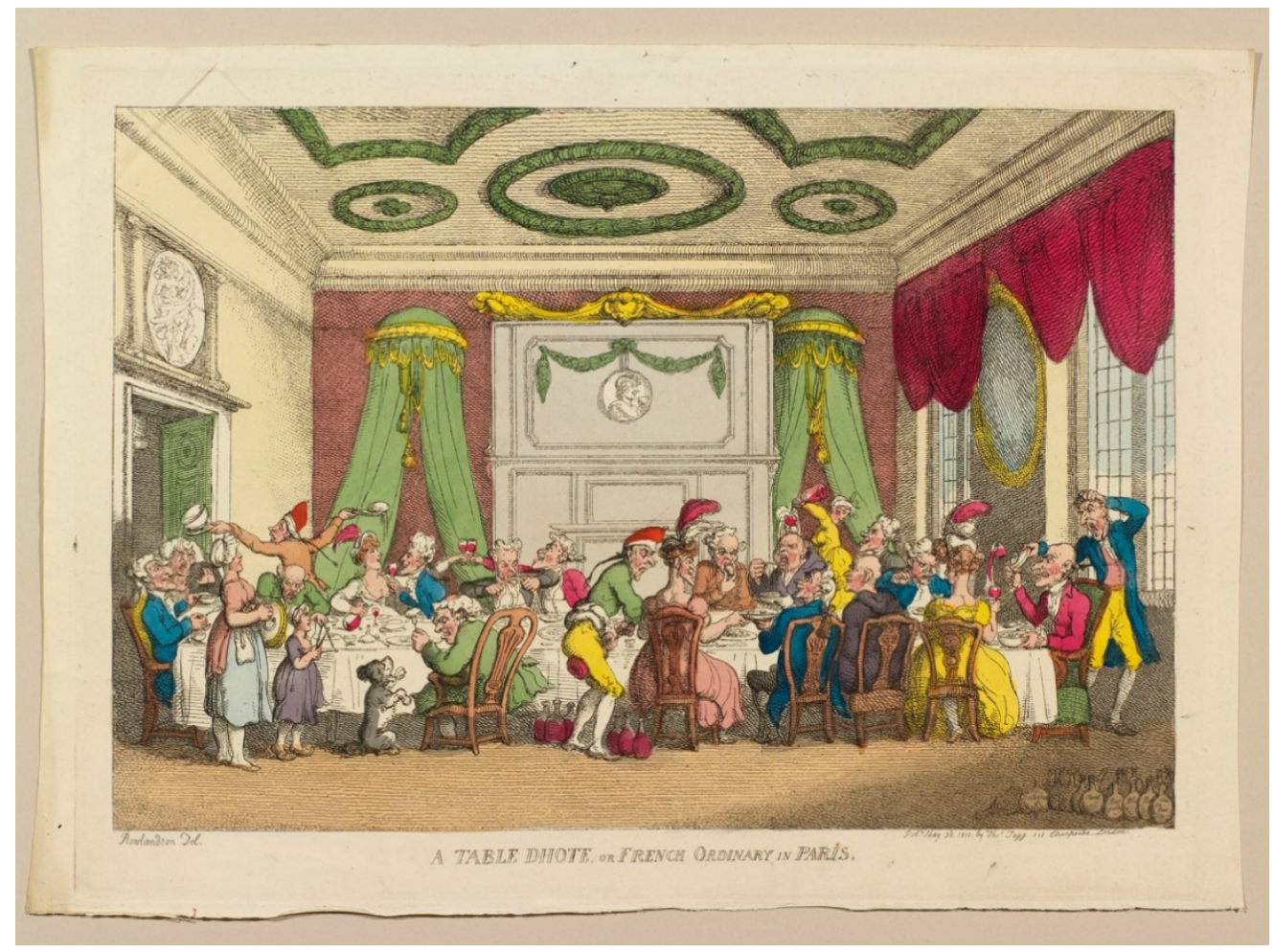

Figure 9: Thomas Rowaldson, A table d'Hote, or French ordinary in Paris, 1810. The Metropolitan Museum of Art. Public domain.

https://www.metmuseum.org/art/collection/search/787707

disgusting flavors and smells, the colors of the dishes both vibrant and dull, the barbaric or civilized ways in which guests chew and drink, all combined in a synesthetic product. The result is a vision of the interior of Portuguese society, displaying with relish the rotten parts as well as the better ones, presenting it as a living organism inevitably constructed by the moral opposites of good and bad. The highlighting of this Manichean concept with the aim of creating alterity - incites in the reader either empathy or repulsion, accompanied by all the other sensations that are stimulated. Critical thinking appears to be a fundamental purpose of Queirós as an author with a clear perception of the time/ framing of his work. His permanent yet subtle sarcasm is the final ingredient to his endeavor.

As demonstrated in the works and authors throughout this essay, the consumption of food and drink is a literary resource used to highlight, caricaturize, criticize, and stress the similarities and differences between characters and their classes and cultures. Some of the alluded authors preferred the elites as the main subjects of their narratives (as in the case of Eça de Queirós), while others focused mainly on a diversity of social and cultural classes (Gil Vicente and António Manuel Policarpo da Silva). All of them, however, intended to make evident the lines that help to give definition to particular 
characters by contrasting those characters with others. They articulate, in short, the identity of self in relation to the "absolute other." This is particularly striking regarding exoticism; frequently the "other" is articulated with both fascination and suspicion. One of the main similarities of the literary excerpts mentioned in this essay is a certain distrust regarding lesser known and very different habits and persons. The racial statements in some of Eça de Queirós's writings must also be stressed, as well as a critical resistance to social and cultural changing processes through the accentuation of the value of ancient, local, pure, untouched and uncorrupted materials and habits (namely through food origin, preparation and consumption). All these features represent the writer as a product of his temporal, geographical and cultural contexts. He also uses food as a powerful tool to articulate racial/ ethnic/ political differentiation. On the other hand, authors also intended to bring into question some (mis/pre)-conceptions about both groups and individuals in Portuguese society. Questioning the societal status quo through criticism and caricature is a strategy for shining light onto questionable aspects of society and promoting change. Queirós's portrayal of poor eating habits as a metaphor for ill bourgeois education or bad character are examples of food and drink as effective ways of showing the decadence but also to its opposite, the virtue - of society, in part or as a whole. Preparation, display and ingestion of drink and food habits are some of the most effective tools when writing to illustrate and expose extremes.

\section{Bibliographie}

\section{Sources and Primary Texts}

As Obras de Gil Vicente, Lisboa, Imprensa Nacional, Casa da Moeda, Lisboa, Universidade de Lisboa, Centro de Estudos de Teatro, 5 vols., 2002 [José Camões José (ed.)].

Cantigas D'Escarnho e de Mal Dizer dos Cancioneiros Medievais Galego-Portugueses, Editorial Galaxia, 1965 [Manuel Rodrigues Lapa (ed.)].

QUEIRÓS, Eça de, A Cidade e as Serras, Lisboa, Livros do Brasil, s.d. 
QUEIRÓS, Eça de, A Relíquia, Lisboa, Livros do Brasil, s.d. [Helena Cidade Moura (ed.)].

QUEIRÓS, Eça de, “Frei Genebro,” Contos, Lisboa, Livros do Brasil, s.d., p. 107-120.

QUEIRÓS, Eça de, “O Francesismo,” Últimas Páginas, Obras de Eça de Queiroz,

Vol. II, Porto, Lello \& Irmão Editores, s.d., p. 813-827.

QUEIRÓS, Eça de, O Primo Basílio, Lisboa, Livros do Brasil, s.d., [Helena Cidade Moura (ed.)].

QUEIRÓS, Eça de, A Capital, Editorial Presença, 2003.

QUEIRÓS, Eça de, Textos de Imprensa, IV da Gazeta de Noticias, Lisboa, INCM, 2002 [Elza Miné e Neuma Cavalcante (ed.)].

QUEIRÓS, Eça de, O Crime do Padre Amaro, Lisboa, INCM, 2000 [Carlos Reis e Maria do Rosário Cunha (ed.)].

QUEIROZ, Eça de, The City and The Mountains, Manchester, Carcanet in association with the Calouste Gulbenkian Foundation, 1994 [R. Campbell (trans.)].

QUEIRÓS, Eça de, O Mandarim, Lisboa, INCM, 1992 [B. Berrini (ed.)].

QUEIRÓS, Eça de, Correspondência, Lisboa, INCM, 1983, vol.1.

QUEIRÓS, Eça de, Páginas de Jornalismo, Porto, Lello \& Irmão Editores, 1981 [A. Pinto de Castro (ed.)].

QUEIRÓS, Eça de, Os Maias. Episódios da vida romântica, Lisboa, Livros do Brasil, 1888.

RESENDE, Garcia de, Vida e feitos d'El-Rey Dom João II, Coimbra, Centro de Estudos de Linguística Geral e Aplicada (CELGA), Faculdade de Letras, Universidade de Coimbra, 2007 [E. Verdelho (ed.)].

RESENDE, Garcia de, Crónica de Dom João II e miscelânea, Imprensa Nacional - Casa da Moeda, 1973 [J. V. Serrão (ed.)].

SILVA, António Manuel Policarpo da, O piolho viajante. Divididas as viagens em mil e uma carapuças, Lisboa, Estúdios Cor, 1973. 
TAVARES, Paulino Mota e PEREIRA, Ana Mafalda, Descoberta e Invenção do Brasil - O amargo e o doce, Sintra, Colares Editora, 2000.

VICENTE, Gil, Auto da Festa: obra desconhecida com uma explicação prévia pelo Conde de Sabugosa, Lisboa, Imprensa Nacional, 1906.

VICENTE, Gil, Tragicomedia Pastoril da Serra da Estrella. Four plays of Gil Vicente, Coimbra, Atlântida Coimbra, 1963.

VICENTE, Gil, Obras completas, [Álvaro Júlio da Costa Pimpão (coord.)], Porto, Livraria Civilização, 1979.

ZURARA, Gomes Eanes de, Crónica da tomada de Ceuta por el-rei D. João I, Lisboa, Academia das Ciências (Série vermelha, $n^{\circ}$ 1767), 1915.

\section{Critical texts}

GOES, Maria Antónia, À mesa com Eça de Queirós, Sintra, Colares Editora, 2004.

PALLA, Maria José “Cozinhar e contar uma história: o imaginário alimentar em Gil Vicente", Actas do Quinto Congresso (1-8 Set. 1996), Oxford, Oxford University, Associação Internacional de Lusitanistas, 1998.

PEIXINHO, Ana Teresa, "Food aesthetics: culinary notes on the work of Eça de Queirós," in Joaquim PINHEIRO, Carmen SOARES (eds.), Food Heritages on Both Sides of the Sea, Coimbra, Coimbra University Press / Annablume, 2016, p. 199-218.

QUITÉRIO, José, Histórias e curiosidades gastronómicas, Lisboa, Assírio e Alvim, 1992. 